\title{
Gender stereotypes in children's television commercials and the effects on consumer purchasing behavior
}

Joanne G. Asztalos

West Virginia University

Follow this and additional works at: https://researchrepository.wvu.edu/etd

\section{Recommended Citation}

Asztalos, Joanne G., "Gender stereotypes in children's television commercials and the effects on consumer purchasing behavior" (2003). Graduate Theses, Dissertations, and Problem Reports. 1365. https://researchrepository.wvu.edu/etd/1365

This Thesis is protected by copyright and/or related rights. It has been brought to you by the The Research Repository @ WVU with permission from the rights-holder(s). You are free to use this Thesis in any way that is permitted by the copyright and related rights legislation that applies to your use. For other uses you must obtain permission from the rights-holder(s) directly, unless additional rights are indicated by a Creative Commons license in the record and/ or on the work itself. This Thesis has been accepted for inclusion in WVU Graduate Theses, Dissertations, and Problem Reports collection by an authorized administrator of The Research Repository @ WVU. For more information, please contact researchrepository@mail.wvu.edu. 
Gender Stereotypes in Children's Television Commercials and the Effects on Consumer Purchasing Behavior

\author{
Joanne G. Asztalos \\ Thesis submitted to the \\ Perley Isaac Reed School of Journalism \\ at West Virginia University \\ in partial fulfillment of the requirements for the degree of \\ Masters of Science \\ in \\ Journalism
}

Terry Wimmer, Ph.D., Chair

Archie Sadar, Professor

Paul Burger, Professor

Carol Zwickel, Ph.D

School of Journalism

Morgantown, West Virginia

2003

Keywords: Advertising, Stereotyping History, Differences in Child Behaviors 


\begin{abstract}
Gender Stereotypes in Children's Television Commercials and the Effects on Consumer Purchasing Behavior
\end{abstract}

Joanne G. Asztalos

This research presents an exploratory investigation on the extent of gender stereotypes portrayed in children's television commercials and the effects on consumer purchasing behavior. The author conducted two studies including a content analysis of viewing 75 children's television commercials, 25 boy, 25 girl, 25 neutral, and documenting evidence of roles, traits, activities, products, speaking parts and settings. Qualitative focus groups were then conducted to correlate the documented gender stereotypes with purchasing behaviors among children between the ages of 6-12. Major findings for this research revealed that there are many gender stereotypes in children's television commercials including the issue that male characters pitch more neutral products than female characters. Findings also revealed that gender stereotypes in commercials influence responsive behavior among boys and girls very differently. 


\section{CONTENTS}

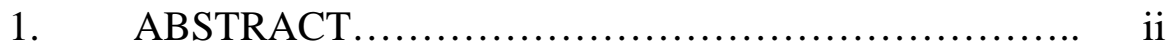

2. INTRODUCTION................................... 1

3. PROBLEMS \& JUSTIFICATIONS.................... 2

4. RESEARCH QUESTION........................... 3

5. LITERATURE REVIEW............................ 4

Learning Stages in Children.................... 4

History of the Child as a Consumer.............. 8

Children and Consumer Behavior............... 12

Gender Roles in Children's Television

Commercials.................................. 14

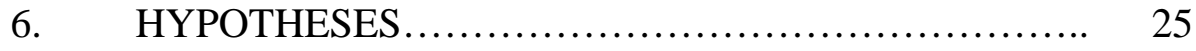

7. METHODOLOGY................................ 26

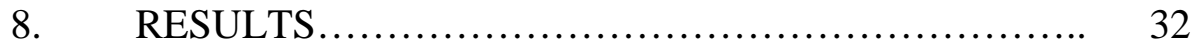

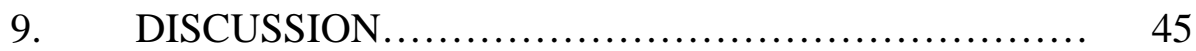

10. STRENGHTS \& LIMITATIONS ..................... 51

11. CONCLUSION..................................... 52

APPENDIX

A. DEFINITION OF TERMS....................... 55

B. STATISTICAL RESULTS FOR 75 CHILDREN'S

TELEVISION COMMERCIALS................... 57

BIBLIOGRAPHY ......................................... 62 


\section{Introduction}

This study examined gender role stereotypes within children’s television commercials and the effects of these messages on consumer purchasing behavior. Children still remain one of the most important groups of consumers for the world of advertising. Turning children into consumers is an important and universally shared goal for this business.

Television is one of the most significant media for the transmission of advertisements to children. From a very young age, children are assigned gender roles that are taught through many influences including television. Children often look to the media to see what the acceptable roles are as a girl or boy. Television advertisements often reinforce these gender stereotypes. Many commercials assign specific gender role characteristics such as boys playing with war toys and girls playing with dolls.

How children interpret these messages and what they do with these messages was also a main area of focus in this study. Throughout their childhoods, they will go through many different learning stages including acquiring knowledge about the world from television advertisements.

The major aspects driving this study included analyzing gender stereotypes in a sample of children's television commercials, along with qualitative research focusing on the effects on consumer purchasing behavior. The purpose of this research was to determine if there is a direct correlation between gender stereotypes within children's commercials and that these messages do have different effects on consumer purchasing behaviors among boys and girls. 


\section{Problems and Justification}

Gender stereotypes in children's commercials have been widely researched for the past several decades. Many previous researchers have studied and pinpointed out distinct gender stereotypes and focused mainly on these specifics about the stereotyping. This study will expand on previous research by taking gender stereotypes and correlating them with consumer purchasing behavior.

Seventy-five commercials aimed directly at children were studied through a content analysis. The sample included 25 commercials aimed at both girls and boys, 25 aimed at boys, and 25 aimed at girls. The sample was taken over a period of six months covering seven different television networks including Nickelodeon, The WB, The Family Channel, Cartoon Network, FOX, NBC, and MTV. The time frame of the taping took place Monday through Friday from 3:30 pm to 6:30 pm, and Saturday from 8:00 am to 11:30 am. These networks and time frames were chosen for the sole purpose of airing the most children's programming on national and cable television during these time frames.

To explore effects on consumer purchasing behavior, four focus groups were conducted in October of 2003. These groups included between 8-10 six to twelve-yearolds. These ages were chosen because they are old enough to participate in this type of focus group, and responses vary due to the different levels of maturity. These ages were also chosen because they are at different learning stages in life and take on different purchasing roles. During these focus groups, the children were shown six commercials and asked to participate in a discussion about what they thought of the product, the characters, and the commercial itself. 
This research hoped to bear out the fact that there are gender stereotypes within children's television commercials, and that these stereotypes do have effects on female vs. male consumer purchasing behavior.

This study benefits not only future research in the field of gender stereotyping among children within the media, but also for future advertising research. Advertising is a business of selling with expected results. Advertisers use different techniques to reach their target audience. Understanding what makes a boy purchase a certain product but not a girl helps to identify the tactics needed to sell again to boys. This assists in determining the motivational drives that make a child want a certain product.

This research also benefits advertising by examining if commercials would be more beneficial in the future if there were no gender stereotypes. For example, if a neutral cereal was being advertised, but gender bias made girls not desire the product or think the product is only for boys, half the audience is not being targeted correctly, thus half the sales are gone.

Gender stereotypes within the media can have many effects on children as they age and develop. These stereotypes can guide behavior to try to fit within expected roles. If children look to these beliefs and conceptions as learning tools, it could have an impact on consumer purchasing behavior. It would be beneficial for advertisers to understand the differences and how they derive.

\section{Research Question}

Are there gender role stereotypes in television commercials targeting children and do these stereotypes affect consumer purchasing behavior throughout childhood? 


\section{Literature Review}

\section{Learning Stages In Children}

In the early 1940s, developmental psychologist, Jean Piaget, developed what he called the “Four Stages of Cognitive Development.” The first of Piaget’s stages is called the sensorimotor stage from $0-2$ years. The characteristics in this stage include the child's ability to imitate, think and memorize. The child will also begin to realize objects don't cease to exist when they are out-of-sight and actions will become more goaloriented. $^{1}$

The next stage is the preoperational stage from 2-7 years. The child begins to develop language skills and think in symbolic forms. The child will also have difficulty seeing another person's point of view. ${ }^{2}$

The third stage is the concrete operational stage from 7-11 years. The child will be able to solve concrete, hands-on problems in a logical fashion. The child will also be able to understand laws of conservation and will be able to classify and understand reversibility. $^{3}$

The final stage is the formal operational stage from 11-15 years. The child will be able to solve abstract problems, will become more scientific, and develop concerns about social issues and identity. ${ }^{4}$

\footnotetext{
${ }^{1}$ Shahnaz Qayumi, “Piaget And His Role In Problem Based Learning.” Journal of Investigative Surgery 14 (2001): 64.

${ }^{2}$ Ibid.

${ }^{3}$ Ibid.

${ }^{4}$ Ibid.
} 
Piaget's stages are important to advertisers because understanding children's capabilities at different ages helps reach their target more directly. It aids in speaking right to the child based on the different levels of learning. For example, in the preoperational stage from 2-7 years old, Piaget states that the child will have difficulty seeing another person's point of view. ${ }^{5}$ If this proves to be true, advertisers should look at different persuasion techniques so the child will be able to see another person's point of view.

In 1956, psychiatrist Erick Erikson introduced “Erikson’s Eight Stages of Development.” His first stage, “trust vs. mistrust” (hope), covers the first year of life. If emotional needs are met, the infant develops a sense of trust. If they are not met, the result is an attitude of mistrust toward the world. The second stage, "autonomy vs. shame and doubt” (will), covers ages 1-3 where the child-basic struggle is between a sense of self-reliance and a sense of self-doubt. In the third stage, "initiative vs. guilt” (purpose), children ages 3-6 achieve a sense of competence and initiative. The fourth stage, “industry vs. inferiority” (competence), children ages 6-12 expand on understanding the world and begin to develop appropriate sex role identities. The fifth stage, "identity vs. role confusion” (fidelity), children ages 12-18 begin the transition from childhood to adulthood and begin to establish a new identity. The final three stages, "intimacy vs. isolation," "generativity vs. self-absorption," and "integrity vs. despair” deal with adults and is not relevant to this research. ${ }^{6}$

\footnotetext{
${ }^{5}$ Ibid.

${ }^{6}$ Stephen Weiland, “Erik Erikson: Ages, Stages and Stories.” Generations 17, no. 2 (Spring/Summer 1993): 20.
} 
Erickson's stages of development are also important for advertisers because they deal more with emotional development. This again helps to target the audience more accurately by understanding what emotions children go through at different ages.

Knowing this helps to sell by using advertising that appeals to emotions and senses during specific stages of maturing.

According to R.L. Selman and D.F. Byrne, between the ages of 4 to 12 children go through four different developmental levels with regards to social perspectives.

At level 0 (egocentric role-taking) the child does not differentiate between views, thoughts, and feelings of self and other. At level 1 (subjective role-taking) the child is aware that identical social situations can be interpreted differently by others through feelings and thoughts. At level 2 (self-reflective role-taking) the child is able to reflect on his or her own behavior from the perspective of another person. At level 3 (mutual roletaking) the child is aware that inner attributes of the self can be the object of another person’s thinking and vice versa. ${ }^{7}$

This research pertains to advertising in a more social perspective. For example, at level 2 the child is able to reflect on his or her own behavior from the perspective of another person. ${ }^{8}$ This involves the child modeling the role of another person to accept him or herself. Advertising can portray these roles and motivate the child's desire to mirror the proposed image.

\footnotetext{
${ }^{7}$ Teun G. van Manen, Pier J. M. Prins, and Paul M. G. Emmelkamp, "Assessing Social Cognitive Skills in Aggressive Children from Development Perspective: The Social Cognitive Skills Test.” Clinical Psychology and Psychotherapy 8 (2001): 342.

${ }^{8}$ Ibid.
} 
In 1983, psychologist Howard Gardner developed "The Seven Types of Intelligence" within children. The first being "linguistic" indicates that these children enjoy writing, reading and telling stories. The second, "logical-mathematical," indicates these children are interested in patterns, categories and relationships. The third, "bodilykinesthetic," indicates these children process knowledge through bodily sensations. The fourth, "spatial," indicates these children think in images and pictures. The fifth, "musical," indicates these children are always singing or drumming to themselves. The sixth, "interpersonal," indicates these children are leaders among their peers and are good at communicating others' feelings. The final type, “intrapersonal," indicates these children are shy and self-motivated. ${ }^{9}$

Gardner’s research categorizes children through intelligence. Again this is relevant for advertisers because persuasion techniques used to sell, should speak to the target market on a level of intelligence they are able to understand. This research is also beneficial when conducting qualitative research groups, such as focus groups, when trying to evaluate results.

According to Michael Geis, in order for children to have the competence to understand commercials, three factors come into play including their linguistic competence, their cognitive competence and their "real world" experience. ${ }^{10}$

Geis found from previous research that preschool children have difficulty with reversible passive sentences such as:

a. The dog chased the cat.

b. The cat was chased by the dog.

\footnotetext{
${ }^{9}$ Daniel Sheehan, “A Primer on Multiple Intelligence.” NEA Today 15, no. 17 (March 1997): 17.

${ }^{10}$ Michael L. Geis, The Language of Television Advertising. New York: Academic Press. 1982. 165.
} 
He states that in order for children to interpret these depends on the child's knowledge of the world.

The language of television advertising directed at children is normally colloquial in style. The use of colloquial style in television advertising serves several ends. It is more personal than formal styles, it is less complex and it also employs a less precise vocabulary than does formal English. ${ }^{11}$

When the goal is to sell, advertisers need to know everything about their target market, especially how to properly speak to them through a medium to make sure the audience understands the message. Geis found that advertisers must speak in colloquial style to children because they better understand simplicity. In his example of "the dog chased the cat" and "the cat was chased by the dog," Geis also found that the message is the same, but can be interpreted differently by children if it isn't portrayed as simply as possible.

\section{History Of The Child As A Consumer}

Marketing directed toward children can be traced back to the early 1890s with the introduction of mass-produced magazines and dime novels. In the early 1900s items such as trading cards, storybooks and dolls were used to entertain children, as well as build brand image by having the products' names printed on the toys. ${ }^{12}$

In the 1930s, advertisers began to use strategies marketing to children during

\footnotetext{
${ }^{11}$ Ibid., 167.

${ }^{12}$ Norma Odom Pecora, The Business of Children's Entertainment. New York: The Guilford Press. 1998. 24.
} 
radio advertisements. ${ }^{13}$ Most of the products advertised were household goods from companies like Kellogg’s, General Mills, and Campbell’s. To get the child’s attention, clubs, premiums and contests were offered with toys as rewards. ${ }^{14}$ Children would want the products with the extra bonus, which, in many cases, turned the child into the purchasing influencer. ${ }^{15}$ Parents were persuaded by their children to buy the product with the premium. ${ }^{16}$

In the mid 1930s, the advertising manager for Carnation mapped out a child's nature through market research that was used to target more precisely, persuade, and to sell more.

Children are inveterate collectors. They are collectors of stamps, coins, bits of cloth, fishhooks, pictures and more.

$>$ Children are joiners. They love clubs and societies. They react just as most adults do to the offer of special club privileges.

$>$ Children are hero worshippers. Perhaps children of the age sought are more attracted to picturesque figures in American history than with any other group of framed heroes and heroines.

$>$ Children can be relied upon to send for something that's free. ${ }^{17}$

During the 1940s and 1950s, technology brought in television. ${ }^{18}$ This era also brought about the baby boom. Youth filled the country and advertising was heard through radio, seen on television and read in specialty magazines. ${ }^{19}$ Advertisers took

\footnotetext{
${ }^{13}$ Ibid., 10.

${ }^{14}$ Ibid.

${ }^{15}$ Ibid.

${ }^{16}$ Ibid.

${ }^{17}$ Daniel Thomas Cook, “The Other 'Child Study': Figuring children as consumers in market research, 1910s-1990s,” Sociological Quarterly 41, no. 3 (Summer 2000): 491.

${ }^{18}$ Pecora, Children's Entertainment. 16.

${ }^{19}$ Ibid.
} 
advantage of marketing household and cleaning products to children to establish brand loyalty. ${ }^{20}$

In the 1960s and 1970s, birthrate and income were increasing in the family household. Marketers began more intense research about the child as a consumer. They were also receiving more feedback from the psychological view of children’s understanding as a consumer. The information received dealt with different strategies that would help in attracting children to the product. ${ }^{21}$

From 1980 to 1990, children were still seen as the primary consumers and influencers for many products. ${ }^{22}$ In the 1990s, in addition to consumers and influences, marketers were paying more attention to the child's habits, especially television viewing habits. ${ }^{23}$ This was to make sure they were advertising during the times children watched TV the most.

From 1900 to 1940, children were seen primarily as influencing family purchases or being encouraged to spend their own money wisely. ${ }^{24}$ With the expanding economy of the 1950s, and the baby boom, "teenagers" came to be defined as a consumer market. By 1980, children as young as five were encouraged to think, "brand label." ${ }^{25}$ The 1990s

\footnotetext{
${ }^{20}$ Ibid.

${ }^{21}$ Ibid., 17.

${ }^{22}$ Ibid.

${ }^{23}$ Ibid.

${ }^{24}$ Ibid., 8.

${ }^{25}$ Ibid.
} 
brought consumer outlets that were previously adult oriented and are now designed specifically for children - Walden Kids, Gap Kids, and Talbot’s Kids and Babies. ${ }^{26}$

The consumer behavior of a child is nurtured within the family. Family members are involved in teaching the child the basic aspects of consumption and consumer needs. According to Scott Ward and Daniel Wackman, parent's general consumer goals for their children included learning price-quality relationships. ${ }^{27}$ Previous studies have also found that family is important in teaching children aspects of consumption. This also includes the child's decision-making on brand and store preferences. Family also influences motives, access to information and the ability to process messages correctly:

A great deal of consumer socialization appears to take place during childhood. During this period, consumer learning involves the acquisition of general and specific orientations, as well as simple and complex consumer skills. General consumption orientations include the acquisition of concepts such as materialism and preferences for brands and understanding the meaning of money. ${ }^{28}$

Family members can also influence factors such as age, social class, and gender. Purchasing decisions made by children might have a lot to do with not only age, but also gender. Being able to correctly process messages and money is learned with age and observation of the family and their roles.

Parents have a substantial impact on their children's media exposure. Parents may exert influence by restricting a child's access or exposure to some media

\footnotetext{
${ }^{26}$ Ibid.

${ }^{27}$ Ibid., 75.

${ }^{28}$ George P. Moschis. Consumer Socialization: A Life-Cycle Perspective. Lexington, M.A.: Lexington Books. 1987. 178.
} 
depending on its content and limiting the time spent with media. ${ }^{29}$

\section{Children and Consumer Behavior}

According to MediaFamily.org, in a recent newsletter it was reported that US children ages 3-17 spend more than $\$ 50$ billion a year on items for their personal use and entertainment. The purchasing influence of children ages 3-17 in the household is estimated at $\$ 340$ billion each year. ${ }^{30}$

Research suggests that a great deal of consumer socialization appears to take place during childhood. As children age familiarity with brand increases. Charles K. Atkin found that brand name recall among children increases about 100 percent with age. $^{31}$

According to George P. Moschis, gender differences in consumer behavior stems from a biological perspective and a sociological perspective.

Sex differences due to biological factors reflect changes in physical appearance and biological functions, while sex differences due to sociological factors stem from sex role relationships and social influence processes. Given that both biological and psychosociological processes are ongoing phenomena, they are likely to have a different impact on the individual's behaviors at different stages in the life cycle. ${ }^{32}$

Gender differences in consumer behavior can start very early in children. Many

\footnotetext{
${ }^{29}$ Federal Trade Commission. “Children as Consumers of Entertainment Media: Media Usage, Marketing Behavior and Influences, and Rating Effects.” Congressional Information Service, Inc., Policy Papers. (Sept. 1, 2000). 6.

${ }^{30}$ MediaFamily.org, “The Teaching Power of Television Advertising,” Newsletter. Available from www.mediafamily.org/activitiesandquizzes/novactivity.shtml: Internet.

${ }^{31}$ Moschis. Consumer Socialization: A Life-Cycle Perspective. 179.

${ }^{32}$ Ibid., 213.
} 
studies have shown that girls are more aware of clothing than boys. In 1963, Jon T. Powell found that girls are more likely to shop around before purchasing. It was also shown that girls are more likely to shop with parents while boys shop more on their own or with friends. ${ }^{33}$ R.K. Avery found in 1979 that differences in consumer behavior among boys and girls might be due to emotional maturity. ${ }^{34}$ These differences could affect the way boys and girls spend money.

Moschis found that girls are more able to discriminate cognitively and retain the information within the message, while boys have the ability to price products and services more accurately. ${ }^{35}$ Moschis suggests that this could be because males acquire a greater independence at a younger age than females. ${ }^{36}$

Moschis and Roy L. Moore conducted a study in 1979 using a variety of products including a wristwatch, a hairdryer, a flashcube, sunglasses, a calculator, batteries, dress shoes, and a wallet. They used three tables to calculate their results. These tables included the information sources used by the sex of the child, decision making by the sex of the child, and the perceived importance of select types of information by product among males and females. ${ }^{37}$

Findings showed that boys had a greater independence in purchasing three of the eight products, where as girls were shown to only have a greater independence when

\footnotetext{
${ }^{33}$ Ibid., 215.

${ }^{34}$ Ibid., 214.

${ }^{35}$ Ibid.

${ }^{36}$ Ibid.

${ }^{37}$ Ibid., 216-219.
} 
purchasing dress shoes. ${ }^{38}$ It was also shown that purchasing independence grew more with age in boys. It also showed that parents, friends and television ads contributed the most to information sources about the products. In the decision making process, the top factors showed that, for girls, if their friends liked the product and if it was well known they were more likely to want the product, and for boys, the want was based on if the product was on sale and if it was well known. ${ }^{39}$

This study is relevant because it shows girls have stronger independent purchasing habits with relatively expensive items such as shoes or clothes. It also shows that brand name, friends, television advertising and parents all play a part in the decision making process for children.

\section{Gender Roles in Children's Television Commercials}

In the early 1960s, the tobacco companies were using stereotypical gender roles to sell cigarettes to young children.

The competing tobacco companies know children make up their minds about whether or not to smoke quite young, and most agree, though no longer openly state, with the Liggett \& Myers' vice president who said of young potential smokers in the early 1960s, 'When he does decide to smoke, we want to get him. ${ }^{40}$

The tobacco companies advertised most of their products during children’s television viewing times. The commercials showed false images of gender roles. Males were portrayed as rugged and adventurous, shown participating in such activities as

\footnotetext{
${ }^{38}$ Ibid.

${ }^{39}$ Ibid.

${ }^{40}$ Ibid., 133.
} 
mountain climbing, athletics, sports and piloting an airplane. ${ }^{41}$ On the other hand, the message for females in these ads was in order for a woman to be attractive and romantic, she needed the help of cigarettes. ${ }^{42}$

In the late 1960s, Mattel marketed “Twist ’N Turn” Barbie. They relied heavily on television airtime during Saturday morning cartoons to advertise their products. In 1967 the commercial for "Twist 'N Turn” Barbie aired. The commercial focused on an incredibly clean, scrubbed, starched and polished little girl. The ad was used to convince girls that this new Barbie was better than the Barbie they owned at the time. ${ }^{43}$

The ad showed that the doll had a new face, real eyelashes, a new hairdo, a new net swimsuit, and she could actually twist and turn. The announcer, Robert Preston of the Music Man, sang about the doll while a line of clean, little girls skipped to a fantasy toy store. ${ }^{44}$ The doll was also shown to have new outfits such as negligee with a lace top, lounging pajamas with a backless bodice, print bras, half-slips and panties with garters. ${ }^{45}$ The purpose of the ad was to mix hard sell, broad flattery and polite plastic sensuality. ${ }^{46}$

In 1979, Renate L. Welch, Aletha Huston-Stein, John C. Wright and Robert Plehal conducted a study on subtle sex-role cues in children's commercials. The study focused on the portrayal and implications of gender stereotyping in advertising. The main purpose of the study was primarily, an examination of the more subtle messages

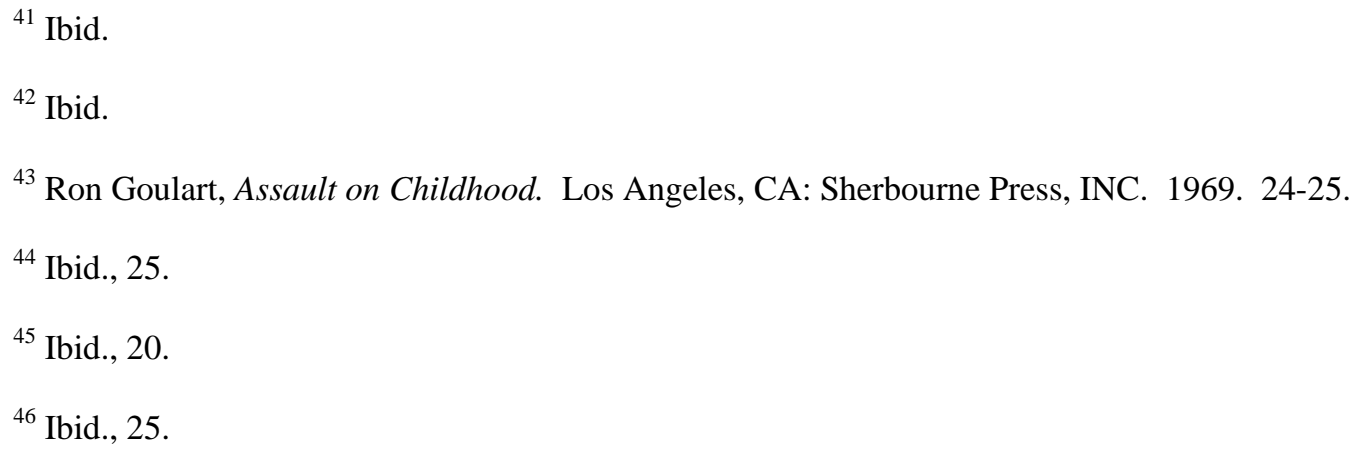


that exist within television referring to production techniques that are employed to achieve particular effects. ${ }^{47}$

The researchers focused on three main areas including determining whether or not different production techniques actually exist; exploring the relationship between advertising and aggressive behavior; and investigating messages about masculine and feminine behavior. They studied 60 commercials, 20 aimed at boys, 20 aimed at girls, and 20 neutral, that aired on weekday and Saturday mornings. They studied the content in terms of five categories; action, pace, visual effects, auditory features and aggression.

Findings for the action category showed that commercials directed at boys have a higher level of activity. It was also found that it is not the boys in the commercials that are shown in action situations as much as it is the products. ${ }^{48}$

For the pace category, findings showed that commercials aimed at boys contained more variability in the form of changing from one scene to another. In the visual effects category, findings showed that commercials for boys contained a higher cutting rate and those for girls included more fades and dissolves. ${ }^{49}$ Commercials for girls showed slower and smoother shifts in view than those for boys. ${ }^{50}$

In the auditory features category, findings showed that a male spokesperson was found more in neutral commercials and commercials aimed at boys, while a female

\footnotetext{
${ }^{47}$ Renate L. Welch, Aletha Huston-Stein, John C. Wright and Robert Plehal, "Subtle Sex-Role Cues in Children’s Commercials,” Journal of Communication 29, no. 3 (Summer 1979): 202.

${ }^{48}$ Ibid., 208.

${ }^{49}$ Ibid.

${ }^{50}$ Ibid.
} 
spokesperson was found primarily in commercials aimed at girls. ${ }^{51}$ Female characters were found to speak very little in neutral commercials. Commercials aimed at boys had louder music and sound effects, while girls' commercials had soft music in the background. ${ }^{52}$ Finally in the aggression category, findings showed instances of violence to be exclusive to commercials aimed at boys. ${ }^{53}$

This study is relevant in that it shows stereotypical gender roles such as boys are loud and violent and girls are quiet, submissive and gentle. It also shows that males have a more dominant role over females by having more speaking parts.

In 1995, Richard H. Kolbe and Darrell Meuhling conducted a study on gender roles and children's television advertising. The purpose of this study was to see if children do or do not attend to gender-role portrayals in television commercials. It was also to see if the gender of the person appearing in the commercial had an effect on the way children evaluate the product. ${ }^{54}$

This research studied elementary students and their responses to modeled behavior within commercials. The researchers focused on the spokesperson on screen and the spokesperson off screen. They also looked to see if children felt the toy was preferred for boys, girls, or both to determine how gender roles in commercials affect wants and desires.

\footnotetext{
${ }^{51}$ Ibid.

${ }^{52}$ Ibid.

${ }^{53}$ Ibid.

${ }^{54}$ Richard H. Kolbe and Darrell Meuhling, “Gender Roles \& Children’s Television Advertising,” Journal of Current Issues and Research in Advertising, 17, no. 1 (1995). 50.
} 
Findings showed that the majority of the children studied were aware of the gender of the spokesperson on screen. However, only 74\% made the correct identification of the gender of the spokesperson off screen (voice-overs). ${ }^{55}$ When they did not identify the spokesperson off screen correctly, they tended to think female voiceovers were actually male. It was also found that there were shifts in judgments when identifying whether the toy was for boys, girls or both. It was mostly shown that boys who saw a female actress connected the product as being for both boys and girls. ${ }^{56}$ When they saw a male actor they connected the product as being for only boys. ${ }^{57}$ The majority of girls who saw a female actress didn't think the product was appropriate for boys only. $^{58}$

This study is relevant because it shows that judgments can be made from the gender of the characters and it can alter the perception of the product.

In 1997, a press release was issued from Children Now, a nonpartisan, independent voice for America’s children titled, “New Studies on Media, Girls, and Gender Roles: Media Reinforces Some Gender Stereotypes, Breaks Others. ${ }^{59}$

A survey was conducted that focused on if women and girls were more likely to be depicted as concerned with romance and dating than work or school and if their

\footnotetext{
${ }^{55}$ Ibid., 58.

${ }^{56}$ Ibid.

${ }^{57}$ Ibid.

${ }^{58}$ Ibid.

${ }^{59}$ Children Now, "New Studies on Media, Girls, and Gender Roles: Media Reinforces Some Gender Stereotypes, Breaks Others,” Press Release for immediate release. April 30, 1997.
} 
appearance was the focus of attention throughout the media. ${ }^{60}$ The survey involved 1,200 children ages 10-17 and asked questions about television shows, commercials, music and teen magazines.

Through a content analysis, findings showed that $56 \%$ of commercials aimed at females show beauty as product appeal, as opposed to only $3 \%$ of commercials aimed at males. ${ }^{61}$ It was also found that $42 \%$ of models in commercials were female and $58 \%$ were male. $^{62}$

This press release is relevant because it shows that female characters are not portrayed as often as males in commercials and when they are, beauty is large focus.

In 1997, Nancy Signorelli, PhD from the University of Delaware for The Kaiser Family Foundation, conducted a study on the reflections of girls in the media. According to Signorelli, the nineties became the decade of media specialization and narrow casting and adolescents emerged as a special advertiser-targeted audience. ${ }^{63}$ The study examined messages from the top 25 television programs for young girls and the commercials before, during and after the programs. ${ }^{64}$

The coding schemes for this study included; demographics, appearance, satisfaction with physical appearance, relationship between appearance and how others perceive the character, solving problems and achieving goals, motivations, topics of

\footnotetext{
${ }^{60}$ Ibid.

${ }^{61}$ Ibid.

${ }^{62}$ Ibid.

${ }^{63}$ Nancy Signorelli, PhD, “A Content Analysis: Reflections of Girls in the Media,” Kaiser Family Foundation, (April, 1997).

${ }^{64}$ Ibid.
} 
conversation, behaviors, activities, and product appeals. Findings showed that women were generally underrepresented. In the commercials studies, there were a total of 465 characters shown. Of that, $42 \%$ were women and $58 \%$ were men. ${ }^{65}$

This study is relevant because it shows that commercials aimed at girls still represent a male dominated world by having more male characters than female.

Another study conducted in 1997 by Moniek Buijzen and Patti M. Vakenburg examined the impact of advertising to children during the high consumption months of the year, from October to December. It focused on gender, age, and level of exposure to the network that aired the most commercials during the holiday season.

There have been studies conducted since the mid 1970s focusing on three types of effects. Cognitive, affective and behavioral effects were used to show how children interpret commercials and understand the message. ${ }^{66}$ Researchers have been conducting these studies to see how children are persuaded by the commercials and how much they trust what they are seeing. ${ }^{67}$ Finding out if television commercials are children's main information source was another purpose of these studies. ${ }^{68}$

Three hypotheses were investigated including children who watch more TV will ask for more advertised products, older children ask for less advertised products, and boys make more requests for advertised products than girls. They studied 250 children between the ages of 7 and 12 in elementary schools across Europe. The children were

\footnotetext{
${ }^{65}$ Ibid.

${ }^{66}$ Moniek Buijzen and Patti M. Valkenburg, “The Impact of Television Advertising on Children’s Christmas Wishes,” Journal of Broadcasting \& Electronic Media 44, no. 3 (Summer 2000): 457.

${ }^{67}$ Ibid.

${ }^{68}$ Ibid.
} 
given a questionnaire about viewing habits, gender and age. Commercials were also recorded on the two most popular children's networks.

Results came back as $51.6 \%$ of the children studied specifically asked for at least one brand that was advertised. ${ }^{69}$ The findings also showed that boys were more exposed to commercials and asked for more advertised products. With these results, all three of the hypotheses were supported. ${ }^{70}$

This research connected brand with age. It showed that the older the child, the more brand name products were wanted. It would probably be good future research to examine the content of commercials directed at different aged children to see if they focus more on the brand name. It would be beneficial to find out the connection between age and brand. Children, as they get older, might become more materialized and that could be the influence of not only peers, but the advertisement message as well. This was a field study conducted in a natural setting, the classroom. However, the researchers mentioned that the study failed to investigate alternative sources of information for gift ideas and how some products connect with fantasies of young children and this is why they were chosen. ${ }^{71}$

In 1999, Katharine Heintz-Knowles, Ph.D. and Meredith Li-Vollmer, conducted a study on boys and men portrayed in the media. The researchers' content included 25 prime time broadcast television programs that had the highest Nielsen ratings among adolescent males, 15 top movies for this age group and 20 music videos most requested

\footnotetext{
${ }^{69}$ Ibid., 460.

${ }^{70}$ Ibid.

${ }^{71}$ Ibid., 463.
} 
on MTV. ${ }^{72}$ Genre, rating, level of sexual and violent content, characters, gender, race, occupation, marital and parental status, primary and secondary motivations, problem solving behaviors and general behaviors were all studied. A national survey was then conducted by Lake Snell Perry \& Associates, polling 1,200 children. ${ }^{73}$

Findings showed children see male characters as leaders and problem solvers. They also see them as funny, successful, confident and athletic. A majority of the children polled said that male characters on television are often portrayed as focused on the opposite sex. It was found that male characters rarely cried and the word sensitive did not describe television's male characters. Three fourths of the children described male characters as violent and angry. Over one third of the children said they never see male characters performing domestic chores like cooking or cleaning. White males were typically seen as consistently motivated by succeeding in work and preventing disaster. Finally, it was shown that the majority of children believed that male characters are different from themselves, other boys they know, fathers and other adult male relatives. ${ }^{74}$

This study is relevant because it shows that the media portrays men in stereotypical gender roles which could be telling young boys that who they see on television is not who they are, but who they are supposed to grow up to be. With everything from anger to race to work, white were seen as strong, independent and problem solvers.

\footnotetext{
${ }^{72}$ Katherine Heintz-Knowles, PhD and Meredith Li-Vollmer, "Boys to Men, Entertainment Media: Messages About Masculinity,” Report from Children \& the Media Program at Children Now, (September 1999). 17.

${ }^{73}$ Ibid.

${ }^{74}$ Ibid., 2.
} 
However, for future research, this study should expand to the upbringings of the sample. It should touch on family life and family roles to uncover if the child considers something to be one way because that's how it is in his/her house, or that's how they were raised.

Daniel Chandler and Merris Griffiths examined specific formal features of advertisements in 2000 such as editing, voice-overs and camera work and their effects on gender.

This study looked at the content of 20 toy commercials aimed at boys, girls and both. The study found that markedly different production techniques were used for boys and girls. ${ }^{75}$ Three hypotheses were studied that included more shots and shorter shots are used for commercials directed toward boys, more dissolves are used for girls, and more male than female voice-overs are likely to be used overall. ${ }^{76}$

One hundred seventeen toy commercials were recorded during the high consumption months from October to December. The researchers make no claim for their choice to study during the holiday season. ${ }^{77}$ Content analysis was used with two key coding tasks. The first was the target audience for the specific commercial, and the second was classifying which ads showed just boys, just girls, and both.

Results indicated that out of the 117 commercials studied, 43 were directed at boys, 43 were directed at girls, and 31 were designed for a neutral audience. The findings also showed that male voices were predominately used for voice-overs and no

\footnotetext{
${ }^{75}$ Daniel Chandler and Merris Griffiths, "Gender-Differentiated Production Features in Toy Commercials," Journal of Broadcasting \& Electronic Media 44, no. 3 (Summer 2000). 505.

${ }^{76}$ Ibid.

${ }^{77}$ Ibid., 505.
} 
female voices were used in the ads directed at boys. The authors also found that boys' ads had more long shots and less close-up shots then in girls' ads. This study's findings showed that the authors' hypotheses were correct. ${ }^{78}$

This study is important because it shows that different production techniques are used when advertising to boys and girls. By using different production techniques in these commercials, they are able to target boys or girls better.

During an interview in 2001 with a cultural anthropology professor and the president of Kurnit Communications, gender in advertising was discussed. William O’Barr, the professor who conducted the interview, asked Paul Kurnit why there is always a white boy, a white girl, an Asian child and an African American child in many children’s commercials. Kurnit answered, “We generally don’t do what looks like a United Nations commercial. If you are in any one commercial trying to pull every

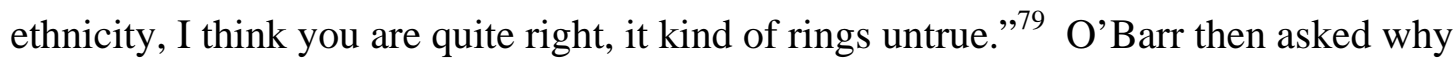
the boy is always white. Kurnit responded with, "Traditionally it is the white boy who would step forward. Why would you have the white boy step forward? Because on some level, mass population is most comfortable with that." ${ }^{80}$

This research shows that again there are race and gender roles in advertising toward children. Kurnit stated that this society feels more comfortable seeing the white boy step forward in the commercial. This could have an affect on the consumer purchasing behavior of a girl; if for instance, the product is neutral like a board game.

\footnotetext{
${ }^{78}$ Ibid., 506-510.

${ }^{79}$ William M. O’Barr, “Interview with Paul Kurnit,” Advertising \& Society Review E, no. 1534-7311. 8.

${ }^{80}$ Ibid., 9.
} 


\section{Hypotheses}

H1- There are fewer female characters than male characters in commercials targeting boys and targeting both boys and girls.

H2 - There are fewer female spokespeople heard and seen in commercials targeting boys and targeting both boys and girls.

H3 - More male characters are primarily shown engaging in action play outdoors with anti-social behavior in neutral and boy commercials.

H4 - More female characters are primarily shown as more sedentary indoors and act with socially acceptable behavior in neutral and girl.

H5 - Neutral commercials advertise more food products and feature more male characters.

H6 - Commercials targeting boys will have faster paced, more intense and louder music then commercials targeting girls.

H7 - There are differences in consumer purchasing behaviors in children based on gender, age and advertising influences.

H8 - Girls pay more attention to commercials and will be more influenced to purchase than boys.

H9 - Boys are more opinionated towards commercials featuring girls or girl products, and girls will be less opinionated towards commercials with boys or pitching a boy product. 


\section{Methodology}

\section{Sample}

The first part of this study included analyzing a sample of 75 commercials targeting children shown on seven different television networks through a content analysis. Out of these 75 commercials, 25 were neutral commercials targeted to both boys and girls, 25 targeted directly at boys, and 25 targeted directly at girls. The sample is an expansion on the “Subtle Sex-Role Cues in Children’s Commercials” study conducted in 1979 by Renate L. Welch, Althea Huston-Stein, John C. Right and Robert Pleahal. ${ }^{81}$ In their study they used a sample of 60 commercials, 20 aimed at boys, 20 aimed at girls and 20 aimed at both. This research expanded this sample by 15 more commercials for a total of 75 . The justification for this sample was to be able to fully examine the distinct and subtle gender role stereotypes in an array of commercials that would not bias the study and would help explain the hypotheses.

The second sample consisted of four focus groups conducted with a total of 38 children between the ages of six and twelve. The 38 children who participated in this study were conveniently chosen from an after-school program that took place in an elementary school in Morgantown, WV. The Institutional Review Board approved this qualitative research and all participants had parental consent. The researcher purposely chose participants for each group that were not siblings or friends to try to avoid biased or influenced responses. The participants viewed six thirty-second commercials taken from the first sample. These commercials included two neutral, two aimed at boys and two

\footnotetext{
${ }^{81}$ Welch, Huston-Stein, Wright and Plehal, “Subtle Sex-Role Cues,” 202.
} 
aimed at girls. The commercials featured three food products, two accessory products, and one toy product.

\section{Procedure}

The 75 commercials were selected over a period of five months on Monday to Friday from 3:30 pm to 6:30 pm and on Saturday mornings from 8:00 am to 11:30 am. According to Children’s Media Education, watching TV is the \#1 after-school activity for 6 to 17 year olds. ${ }^{82}$ A sample of seven different television networks were chosen because the stations aired the most children's programming during the times listed above that also have outside advertising. During these times, the chosen networks aired cartoons, music videos, children’s sitcoms and family oriented shows. On Saturday mornings, the networks aired these shows usually beginning at 8:00 am and run either all day, or some stations, such as NBC or Fox, usually end airing children's programming around 11:30 am. The chosen stations for this study included Nickelodeon, The WB, The Family Channel, Cartoon Network, FOX, NBC, and MTV.

According to Edmund O. Lawler, Nickelodeon reaches more than 300 million households worldwide, is a top outlet in children’s television, and “SpongeBob SquarePants," which airs on Nickelodeon, has been the top-rated show for children ages 2-11 since the third quarter 2001. ${ }^{83}$ Along with Nickelodeon, the Cartoon Network ranks number two in children's advertising revenues. ${ }^{84}$

\footnotetext{
${ }^{82}$ Center for Media Education, “Children \& Television: Frequently Asked Questions. Available from www.cme.org/children/kids_tv/c_and_t.html; Internet; accessed 3 March 2003.

${ }^{83}$ Edmund O. Lawler, “Marketing to Kids, Tweens and Teens,” Advertising Age (February, 17, 2003). S4. ${ }^{84}$ Ibid,.
} 
According to PBS, in 2001 MTV globally reached 350 million households, and is almost non-stop advertising. ${ }^{85}$ In 2000, Neilson Media Research found that 39\% of MTV viewers are under the age of eighteen. ${ }^{86}$

Each commercial was coded and analyzed through a manifest content analysis. This was built from a variety of categories and subcategories that focus on gender stereotyping, see Appendix A. These categories included:

1. The type of advertisement (PSA, testimonial, generic, USP, brand imaging and positioning)

2. The product (food, accessories, clothing, toys, entertainment, educational and other)

3. Characters

- Number of males shown vs. number of females shown

- $\quad 0-2$

- 3-6

- 7-10

- 10 and up

- Role of male characters vs. role of female characters

- Action role

- Sedentary role

- None

- Speaking parts for males vs. speaking parts for females

- None

- $1-3$

- $4-6$

- 7 and up

\footnotetext{
${ }^{85}$ Mediafamily.org, “MTV Fact Sheet.” Available from www.mediafamily.org/facts/facts_mtv.shtml: Internet. April 1, 2003.

${ }^{86}$ Ibid.
} 
- Male behavior vs. female behavior

- Anti-social behavior

- Social behavior

- None

- Male announcers vs. female announcers

- Male announcer shown

- Male announcer not shown

- Female announcer shown

- Female announcer not shown

4. The setting

- Where the commercial takes place

- Indoors

- Outdoors

- Both

- Other

- The type of setting

- Realistic

- Cartoon

- Claymation

- Combination

5. The situation type (playtime, fantasy, action/adventure, real life, fashion/trends, futuristic, and other)

6. Background music (romantic, hip hop, rap, fast paced, slow paced, action, other, and none)

The categories were chosen from past research. Activity and auditory 
features were two categories used in the “Subtle Sex-Role Cues in Children’s

Commercials” study. ${ }^{87}$ In Richard H. Kolbe and Darrell Meuhling’s study, “Gender Roles \& Children's Television Advertising,” they focused their categories on the sex of the actor/actress and the sex of the spokesperson. ${ }^{88}$ This research identifies the sex of the actors/actress, the sex of the spokesperson, and if the spokesperson was shown or if just the voice was heard. These categories are based from the study conducted by Daniel Chandler and Merris Griffiths in 2000, “Gender-Differentiated Production Features in Toy Commercials.”89

This study also focused on the representation of males vs. females which was the basis of Nancy Signorelli, Ph.D.’s study in 1997, “A Content Analysis: Reflections of Girls in the Media.”90 Along with representation, roles of the characters were examined based around Katherine Heintz-Knowles, Ph.D. and Meredith Li-Vollmer’s study, “Boys to Men, Entertainment media: Messages About Masculinity."91 This research expanded on that by examining not only the roles of males but females as well.

After the complete content analysis of the 75 commercials, a qualitative study was conducted to determine how children process these messages and how they affect consumer purchasing behavior. According to George P. Moschis, viewing television

\footnotetext{
${ }^{87}$ Welch, “Subtle Sex-Role Cues,” 202.

${ }^{88}$ Kolbe and Meuhling, “Gender Roles \& Children’s Television Advertising,” 50.

${ }^{89}$ Chandler and Griffiths, “Gender-Differentiated Production Features in Toy Commercials,” 503-521.

${ }^{90}$ Signorelli, "Reflections of Girls in Media,” 1-8.

${ }^{91}$ Heintz-Knowles and Li-Vollmer, “Boys to Men,” 1-18.
} 
commercials that frequently portray traditional sex roles might lead to the development of stereotypical sex role conceptions regarding consumer decisions among children. ${ }^{92}$

Four focus groups of eight to ten children between the ages of six and twelve were conducted. These age groups were chosen because there is an age difference, a maturity difference, a different level of understanding, and they might be at different levels of learning stages but are exposed to the same messages. Group number one consisted of one boy age 6 , two girls age 6 , one boy age 8 , one boy age 9 , two girls age 10, one boy age 11, one boy age 12, and one girl age 12. Group number two consisted of one girl age 6 , two boys age 7 , two girls age 9 , three boys age 10 , and two girls age 11 . Group number three consisted of three boys age 7, two girls age 7, two girls age 9, and one boy age 12. Group number four consisted of one boy age 6, two girls age 7, one girl age 8 , two boys age 8 , two girls age 9 , one boy age 10 , and one boy age 11 .

The participants were asked to write down some of their favorite things to purchase and if they saw the product advertised on television. They were then shown the six thirty-second commercials and were asked to comment on each individual one. A boy commercial was shown first, followed by a girl commercial, a neutral commercial, a boy commercial, a girl commercial and finally another neutral commercial. Each commercial was chosen based on the results of the content analysis.

After viewing each commercial the children were asked to participate in a discussion about what they saw and how they perceived it. The subjects were asked a series of closed and open-ended questions regarding purchasing behavior and feelings towards the commercials viewed. Some sample questions asked included;

- What are commercials?

${ }^{92}$ Moschis, “Consumer Socialization: A Life-Cycle Perspective,” 127. 
- What makes commercials good?

- What is your favorite commercial?

- Is this a toy/product you have?

- Is this a toy/product you want to have? Why or why not?

- Do your favorite commercials make you want to buy things? What things?

- Was there a man or woman spokesperson in the commercial?

- What does purchasing mean?

- Do you purchase things? What things?

Focus groups were used in this study to discover underlying motivations, attitudes and perceptions of the participants. The different age groups were selected in order to find out if age plays a difference in the understanding of messages and consumer purchasing behavior.

\section{Results}

\section{Neutral Commercials}

--Table 1 Neutral--

The first variable studied in the content analysis was the type of advertisement. The analysis of this variable revealed that unique selling proposition advertisements were most frequently seen at 52 percent.

Table 1 - Type of Advertisement N=25

\begin{tabular}{|c|c|}
\hline Advertisement & Percentage \\
\hline USP & 52.0 \\
\hline Positioning & 12.0 \\
\hline Brand Image & 12.0 \\
\hline Generic & 12.0 \\
\hline PSA & 12.0 \\
\hline Testimonial & 0.0 \\
\hline
\end{tabular}


--Table 2 Neutral--

The second variable, the product, revealed that food products were advertised the most at 72 percent.

Table 2 - The Product N=25

\begin{tabular}{|c|c|}
\hline Product & Percentage \\
\hline Food & 72.0 \\
\hline Educational & 16.0 \\
\hline Entertainment & 8.0 \\
\hline Toys & 4.0 \\
\hline Accessories & 0.0 \\
\hline Clothing & 0.0 \\
\hline
\end{tabular}

--Table 3 Neutral--

The third and fourth variables studied were the number of male characters seen and the number of female characters seen in neutral commercials.

Table 3 - Male vs. Female Characters Seen $\mathrm{N}=25$

\begin{tabular}{|c|c|c|c|c|}
\hline \multicolumn{7}{|c|}{ (Represented in Percentage) } \\
\hline $\begin{array}{l}\text { Number of } \\
\text { Characters }\end{array}$ & $\mathbf{0 - 2}$ & $\mathbf{3 - 6}$ & $\mathbf{7 - 1 0}$ & $\mathbf{1 0}$ and up \\
\hline Males & 28.0 & 56.0 & 12.0 & 4.0 \\
\hline Females & 72.0 & 28.0 & 0.0 & 0.0 \\
\hline
\end{tabular}

--Table 4 Neutral--

The fifth and sixth variables studied the roles that male characters portrayed and the roles female characters played in neutral commercials. 
Table 4 - Roles for Males vs. Females N=25

\begin{tabular}{|c|c|c|c|}
\hline (Represented in Percentage) \\
\hline Mole & Action & Sedentary & $\begin{array}{c}\text { No } \\
\text { Role }\end{array}$ \\
\hline Females & 72.0 & 28.0 & 0.0 \\
\hline
\end{tabular}

--Table 5 Neutral--

The seventh and eighth variables studied the number of speaking parts for males and for females in neutral commercial.

Table 5 - Speaking Parts for Males vs. Females N=25

(Represented in Percentage)

\begin{tabular}{|c|c|c|c|c|}
\hline Speaking Parts & None & $\mathbf{1 - 3}$ & $\mathbf{4 - 6}$ & $\mathbf{7}$ and up \\
\hline Males & 24.0 & 64.0 & 12.0 & 0.0 \\
\hline Females & 64.0 & 36.0 & 0.0 & 0.0 \\
\hline
\end{tabular}

--Table 6 Neutral--

The ninth and tenth variables studied male behavior and female behavior among the characters in neutral commercials.

Table 6 - Male Behavior vs. Female Behavior N=25

\begin{tabular}{|c|c|c|c|}
\hline \multicolumn{4}{|c}{ (Represented in Percentage) } \\
\hline Behavior & $\begin{array}{c}\text { Anti- } \\
\text { social }\end{array}$ & Social & $\begin{array}{c}\text { No } \\
\text { Behavior }\end{array}$ \\
\hline Males & 32.0 & 68.0 & 0.0 \\
\hline Females & 0.0 & 68.0 & 32.0 \\
\hline
\end{tabular}

--Table 7 Neutral--

The eleventh variable studied the announcers within neutral commercials. This revealed that male announcers who were not shown in the commercial were used most frequently at 88 percent. 
Table 7 - Announcers N=25

\begin{tabular}{|c|c|}
\hline Announcer & Percentage \\
\hline $\begin{array}{c}\text { Male Announcer Not } \\
\text { Shown }\end{array}$ & 88.0 \\
\hline $\begin{array}{c}\text { Female Announcer Not } \\
\text { Shown }\end{array}$ & 8.0 \\
\hline Male Announcer Shown & 4.0 \\
\hline Female Announcer Shown & 0.0 \\
\hline
\end{tabular}

--Table 8 Neutral--

The twelfth variable focused on the setting and where the commercial took place.

This revealed that the majority of neutral commercials took place indoors at 60 percent.

Table 8 - Setting (where it takes place) $\mathrm{N}=25$

\begin{tabular}{|c|c|}
\hline Setting & Percentage \\
\hline Indoors & 60.0 \\
\hline Both & 24.0 \\
\hline Outdoors & 16.0 \\
\hline
\end{tabular}

--Table 9 Neutral--

The thirteenth variable studied the setting type. Realistic settings were seen most frequently at 52 percent in neutral commercials.

Table 9 - Setting Type N=25

\begin{tabular}{|c|c|}
\hline Setting Type & Percentage \\
\hline Realistic & 52.0 \\
\hline Combination & 24.0 \\
\hline Cartoon & 16.0 \\
\hline Claymation & 8.0 \\
\hline
\end{tabular}

--Table 10 Neutral--

The fourteenth variable studied the situation type. Playtime situations were used most often at 24 percent in neutral commercials. 
Table 10 - Situation Type N=25

\begin{tabular}{|c|c|}
\hline Situation Type & Percentage \\
\hline Playtime & 24.0 \\
\hline Fantasy & 20.0 \\
\hline Action/Adventure & 20.0 \\
\hline Real Life & 20.0 \\
\hline Other & 12.0 \\
\hline Fashion/Trends & 4.0 \\
\hline
\end{tabular}

--Table 11 Neutral--

The fifteenth variable studied the type of music played in the background of neutral commercials. This revealed that the majority of neutral commercials had no music at all at 36 percent.

Table $11-$ Music N=25

\begin{tabular}{|c|c|}
\hline Music & Percentage \\
\hline None & 36.0 \\
\hline Fast Paced & 32.0 \\
\hline Hip Hop & 12.0 \\
\hline Other & 8.0 \\
\hline Slow Paced & 8.0 \\
\hline Romantic & 4.0 \\
\hline Action & 0.0 \\
\hline Rap & 0.0 \\
\hline
\end{tabular}

\section{Boy Commercials}

--Table 1 Boy--

The type of advertisement for commercials targeting boys revealed that USP ads were seen most frequently at 44 percent. 
Table 1 - Type of Advertisement N=25

\begin{tabular}{|c|c|}
\hline Advertisement & Percentage \\
\hline USP & 44.0 \\
\hline Brand Image & 24.0 \\
\hline Positioning & 32.0 \\
\hline Generic & 0.0 \\
\hline PSA & 0.0 \\
\hline Testimonial & 0.0 \\
\hline
\end{tabular}

--Table 2 Boys--

Products targeting boys revealed that toys were the most frequently advertised at 68 percent.

Table 2 - The Product N=25

\begin{tabular}{|c|c|}
\hline Product & Percentage \\
\hline Toys & 68.0 \\
\hline Entertainment & 12.0 \\
\hline Food & 8.0 \\
\hline Accessories & 8.0 \\
\hline Clothing & 4.0 \\
\hline Educational & 0.0 \\
\hline
\end{tabular}

--Table 3 Boys--

The number of male characters and the number of female characters seen in boy commercials revealed that in all twenty-five commercials there was not one female character seen.

Table 3 - Male vs. Female Characters Seen N=25

(Represented in Percentage)

\begin{tabular}{|c|c|c|c|c|}
\hline $\begin{array}{c}\text { Number of } \\
\text { Characters }\end{array}$ & $\mathbf{0 - 2}$ & $\mathbf{3 - 6}$ & $\mathbf{7 - 1 0}$ & $\mathbf{1 0}$ and up \\
\hline Males & 36.0 & 36.0 & 16.0 & 12.0 \\
\hline Females & 0.0 & 0.0 & 0.0 & 0.0 \\
\hline
\end{tabular}


The role of males and females in boy commercials revealed that 96 percent of male characters took on an action role. There were no girl characters, so there were no roles to report.

Table 4 - Roles for Males vs. Females N=25

(Represented in Percentage)

\begin{tabular}{|c|c|c|c|}
\hline Role & Action & Sedentary & $\begin{array}{c}\text { No } \\
\text { Role }\end{array}$ \\
\hline Males & 96.0 & 4.0 & 0.0 \\
\hline Females & 0.0 & 0.0 & 100.0 \\
\hline
\end{tabular}

--Table 5 Boys--

Speaking parts for males in boy commercials revealed that 88 percent of male characters had between one to three speaking parts per commercial. There were no girls seen, so there were no female speaking parts.

Table 5 - Speaking Parts for Males vs. Females N=25

\begin{tabular}{|c|c|c|c|c|}
\hline (Represented in Percentage) \\
\hline Speaking Parts & None & $\mathbf{1 - 3}$ & $\mathbf{4 - 6}$ & $\mathbf{7}$ and up \\
\hline Males & 4.0 & 88.0 & 4.0 & 4.0 \\
\hline Females & 100.0 & 0.0 & 0.0 & 0.0 \\
\hline
\end{tabular}

--Table 6 Boys--

Behavior among characters in boy commercials revealed that 68 percent of males acted in an anti-social behavior. There were no girls seen, so there were no behaviors to report for girls. 
Table 6 - Male Behavior vs. Female Behavior N=25

\begin{tabular}{|c|c|c|c|}
\hline (Represented in Percentage) \\
\hline Behavior & $\begin{array}{c}\text { Anti- } \\
\text { social }\end{array}$ & Social & $\begin{array}{c}\text { No } \\
\text { Behavior }\end{array}$ \\
\hline Males & 68.0 & 32.0 & 0.0 \\
\hline Females & 0.0 & 0.0 & 100.0 \\
\hline
\end{tabular}

--Table 7 Boys--

In all twenty-five commercials targeting boys there were only male announcers that were not shown.

Table 7 - Announcers $\mathrm{N}=25$

\begin{tabular}{|c|c|}
\hline Announcer & Percentage \\
\hline $\begin{array}{c}\text { Male Announcer Not } \\
\text { Shown }\end{array}$ & 100.0 \\
\hline $\begin{array}{c}\text { Female Announcer Not } \\
\text { Shown }\end{array}$ & 0.0 \\
\hline Male Announcer Shown & 0.0 \\
\hline Female Announcer Shown & 0.0 \\
\hline
\end{tabular}

--Table 8 Boys--

It was revealed that 36 percent of commercials targeting boys took place indoors.

Table 8 - Setting (where it takes place) $\mathrm{N}=25$

\begin{tabular}{|c|c|}
\hline Setting & Percentage \\
\hline Indoors & 36.0 \\
\hline Outdoors & 32.0 \\
\hline Both & 24.0 \\
\hline
\end{tabular}

--Table 9 Boys--

Among setting type for commercials targeting boys, realistic settings were most frequently seen. 
Table 9 - Setting Type N=25

\begin{tabular}{|c|c|}
\hline Setting Type & Percentage \\
\hline Realistic & 64.0 \\
\hline Combination & 20.0 \\
\hline Cartoon & 12.0 \\
\hline Claymation & 4.0 \\
\hline
\end{tabular}

--Table 10 Boys--

The majority of boy commercials had a playtime type of setting at 40 percent.

Table 10 - Situation Type $\mathbf{N}=25$

\begin{tabular}{|c|c|}
\hline Situation Type & Percentage \\
\hline Playtime & 40.0 \\
\hline Action/Adventure & 32.0 \\
\hline Other & 20.0 \\
\hline Fantasy & 4.0 \\
\hline Fashion/Trends & 4.0 \\
\hline Real Life & 0.0 \\
\hline
\end{tabular}

--Table 11 Boys--

Fast paced music was most frequently heard among commercials targeting boys at 60 percent.

Table 11 - Music N=25

\begin{tabular}{|c|c|}
\hline Music & Percentage \\
\hline Fast Paced & 60.0 \\
\hline Rap & 8.0 \\
\hline Hip Hop & 8.0 \\
\hline Other & 8.0 \\
\hline Slow Paced & 8.0 \\
\hline Action & 8.0 \\
\hline Romantic & 0.0 \\
\hline None & 0.0 \\
\hline
\end{tabular}




\section{Girl Commercials}

--Table 1 Girl--

In commercials targeting girls it was revealed that positioning advertisements were used most frequently at 36 percent.

Table 1 - Type of Advertisement N=25

\begin{tabular}{|c|c|}
\hline Advertisement & Percentage \\
\hline Positioning & 36.0 \\
\hline USP & 32.0 \\
\hline Generic & 24.0 \\
\hline Brand Image & 8.0 \\
\hline PSA & 0.0 \\
\hline Testimonial & 0.0 \\
\hline
\end{tabular}

--Table 2 Girls--

Toy products were most frequently advertised to girls at 32 percent and that every type of studied product was advertised to girls.

Table 2 - The Product N=25

\begin{tabular}{|c|c|}
\hline Product & Percentage \\
\hline Toys & 32.0 \\
\hline Entertainment & 28.0 \\
\hline Accessories & 24.0 \\
\hline Clothing & 8.0 \\
\hline Educational & 4.0 \\
\hline Other & 4.0 \\
\hline
\end{tabular}

--Table 3 Girls--

In commercials targeting girls, it was revealed that there were some male characters featured in the ad. 
Table 3 - Male vs. Female Characters Seen N=25

\begin{tabular}{|c|c|c|c|c|}
\hline $\begin{array}{c}\text { Number of } \\
\text { Characters }\end{array}$ & $\mathbf{0 - 2}$ & $\mathbf{3 - 6}$ & $\mathbf{7 - 1 0}$ & $\mathbf{1 0}$ and up \\
\hline Males & 96.0 & 4.0 & 0.0 & 0.0 \\
\hline Females & 28.0 & 64.0 & .0 & 0.0 \\
\hline
\end{tabular}

--Table 4 Girls--

The majority for both male characters and female characters took on a sedentary role in commercials targeting girls.

Table 4 - Roles for Males vs. Females N=25

(Represented in Percentage)

\begin{tabular}{|c|c|c|c|}
\hline Role & Action & Sedentary & $\begin{array}{c}\text { No } \\
\text { Role }\end{array}$ \\
\hline Males & 12.0 & 36.0 & 52.0 \\
\hline Females & 44.0 & 56.0 & 0.0 \\
\hline
\end{tabular}

--Table 5 Girls--

Female characters had more speaking parts then male characters, but it was revealed that male characters still had some speaking parts in girl commercials.

Table 5 - Speaking Parts for Males vs. Females N=25 (Represented in Percentage)

\begin{tabular}{|c|c|c|c|c|}
\hline Speaking Parts & None & $\mathbf{1 - 3}$ & $\mathbf{4 - 6}$ & $\mathbf{7}$ and up \\
\hline Males & 68.0 & 32.0 & 0.0 & 0.0 \\
\hline Females & 4.0 & 88.0 & 4.0 & 0.0 \\
\hline
\end{tabular}

--Table 6 Girls--

The majority of female behavior in girl commercials was social at 96 percent. 
Table 6 - Male Behavior vs. Female Behavior N=25

\begin{tabular}{|c|c|c|c|}
\hline \multicolumn{4}{|c}{ (Represented in Percentage) } \\
\hline Behavior & $\begin{array}{c}\text { Anti- } \\
\text { social }\end{array}$ & Social & $\begin{array}{c}\text { No } \\
\text { Behavior }\end{array}$ \\
\hline Males & 4.0 & 44.0 & 52.0 \\
\hline Females & 4.0 & 96.0 & 0.0 \\
\hline
\end{tabular}

--Table 7 Girls--

Female announcers who were not shown were heard most frequently in commercials targeting girls at 60 percent.

Table 7 - Announcers N=25

\begin{tabular}{|c|c|}
\hline Announcer & Percentage \\
\hline $\begin{array}{c}\text { Female Announcer Not } \\
\text { Shown }\end{array}$ & 60.0 \\
\hline $\begin{array}{c}\text { Male Announcer Not } \\
\text { Shown }\end{array}$ & 28.0 \\
\hline Female Announcer Shown & 12.0 \\
\hline Male Announcer Shown & 0.0 \\
\hline
\end{tabular}

--Table 8 Girls--

The majority of commercials targeting girls took place indoors at 56 percent.

Table 8 - Setting (where it takes place) $\mathrm{N}=25$

\begin{tabular}{|c|c|}
\hline Setting & Percentage \\
\hline Indoors & 56.0 \\
\hline Both & 40.0 \\
\hline Outdoors & 4.0 \\
\hline
\end{tabular}

--Table 9 Girls--

The majority of commercials targeting girls had a realistic setting type at 52 percent. 
Table 9 - Setting Type N=25

\begin{tabular}{|c|c|}
\hline Setting Type & Percentage \\
\hline Realistic & 52.0 \\
\hline Cartoon & 16.0 \\
\hline Combination & 32.0 \\
\hline Claymation & 0.0 \\
\hline
\end{tabular}

--Table 10 Girls--

The majority of commercials targeting girls had a fashion and trendy situation type at 52 percent.

Table 10 - Situation Type N=25

\begin{tabular}{|c|c|}
\hline Situation Type & Percentage \\
\hline Fashion/Trends & 52.0 \\
\hline Fantasy & 12.0 \\
\hline Other & 12.0 \\
\hline Playtime & 12.0 \\
\hline Real Life & 8.0 \\
\hline Action/Adventure & 4.0 \\
\hline
\end{tabular}

--Table 11 Girls--

It was revealed that hip hop music was most frequently heard in the background of commercials targeting girls at 64 percent.

Table 11 - Music N=25

\begin{tabular}{|c|c|}
\hline Music & Percentage \\
\hline Hip Hop & 64.0 \\
\hline Slow Paced & 16.0 \\
\hline Fast Paced & 16.0 \\
\hline Romantic & 4.0 \\
\hline Rap & 0.0 \\
\hline Action & 0.0 \\
\hline Other & 0.0 \\
\hline None & 0.0 \\
\hline
\end{tabular}




\section{Discussion}

The main drive of this study was to investigate to what extent gender stereotypes are portrayed within television commercials targeting children and how these stereotypes affect consumer purchasing behavior. The findings for the content analysis revealed that there are an abundant amount of gender stereotypes within children's commercials, see Appendix B.

The first hypothesis (H1) predicted that there would be fewer female characters in commercials targeting boys and targeting both boys and girls. This hypothesis was accepted. It was found that in neutral commercials male characters were seen more often and in a larger abundance than female characters, and in the boy commercials there were no female characters featured at all.

The second hypothesis (H2) predicted there would be fewer female spokespeople in commercials targeting boys and targeting both boys and girls. This hypothesis was accepted. Results revealed that male spokespeople were featured in all twenty-five commercials targeting boys. In neutral commercials it was revealed that $92 \%$ had male spokespeople and only $8 \%$ had female spokespeople. Only $4 \%$ of spokespeople were actually seen in neutral commercials and that percentage was male.

The third hypothesis (H3) predicted that more male characters would be primarily shown engaging in action play outdoors with anti-social behavior in neutral and boy commercials. This hypothesis was partially accepted. Neutral commercials revealed that $72 \%$ of male characters engaged in action play, however, $68 \%$ of male characters had social behavior and the majority of neutral commercials took place indoors. Boy 
commercials revealed that $96 \%$ of male characters engaged in action play and $68 \%$ acted with anti-social behavior. The majority of boy commercials also took place indoors.

The fourth hypothesis (H4) predicted that more female characters would be primarily shown as more sedentary indoors and act with socially acceptable behavior in neutral commercials and girl commercials. This hypothesis was accepted. Results for neutral commercials revealed that $56 \%$ of female characters engaged in sedentary play, $68 \%$ acted with socially acceptable behavior, and $60 \%$ took place indoors. Girl commercials revealed that $56 \%$ of female characters engaged in sedentary play, $96 \%$ acted with socially acceptable behavior, and 56\% took place indoors.

The fifth hypothesis (H5) predicted that neutral commercials would advertise more food products and feature more male characters. This hypothesis was accepted. Results revealed that 72 percent of the neutral commercials were pitching food products. It was also revealed that there were more male characters making more appearances in these commercials than females.

The sixth hypothesis (H6) predicted that commercials targeting boys would have faster paced, more intense and louder music than commercials targeting girls. This hypothesis was accepted. Results revealed that $60 \%$ of boy commercials played fast music in the background.

The seventh hypothesis (H7) predicted that there would be differences in consumer purchasing behaviors in children based on gender, age and advertising influences. Hypothesis 8 (H8) predicted that girls would pay more attention to commercials and would be more influenced to purchase than boys. Hypothesis 9 (H9) predicted that boys would be more opinionated toward commercials featuring girls or girl 
products, and girls would be less opinionated toward commercials with boys or that pitch boy products. All three of these hypotheses were accepted as revealed through the following results from the focus groups.

The most important findings from these groups include the following:

\section{This research confirms that all the participants watch and love television, however boys do not like commercials.}

Television viewing is a highly universal leisure activity for children between the ages of 6 to 12. Children love watching TV and it was found that their favorite television shows are aired on the networks that were used in the content analysis for this research.

Boys agree that commercials are boring and say they do not usually pay attention to them. They will change the channel, leave the room, or engage in another activity until their program has returned.

Boys have a stronger opinion about disliking commercials than girls. They “just hate them" and are less sure why they hate them. Girls just like "cool” commercials.

\section{There are different purchasing behaviors among boys and girls, which also is a direct correlation with age.}

There is a fairly universal group of purchases that girls buy and that boys buy. Younger girls are more interested in purchasing dolls and stuffed toys and older girls are more interested in purchasing clothes and accessories. Boys between the ages of 6 to 12 are more interested in purchasing toys and video games.

As far as purchasing roles among kids are concerned, younger children tell their parents what they want and the parents do the purchasing. Younger children play the role 
of the influencer. Older children also tell their parents what they want, but they do some purchasing on their own as well.

\section{Finding out about products varies from boys to girls.}

Girls see the majority of the products they want to purchase by viewing commercials. Girls pay more attention to what the product is that is being advertised.

Boys see the majority of the products they want to purchase through other boys who already have the product or through viewing television programs.

\section{Girls and boys behaviors and attitudes vary from viewing different types of gender related commercials.}

Boys are more opinionated when viewing commercials. Boys like boy targeted commercials. Boys say they dislike any commercial that is targeted toward girls.

Boys are less responsive to neutral commercials, but heavily opinionated toward neutral commercials that have girls pitching the product.

\footnotetext{
“Those girls are stupid.”

“Girls can’t drive a Jeep.”

"Food shopping is only for girls."

“Those girls are annoying.”

“Shut your eyes, there’s girls on the screen."
}

Boys pay more attention to the content of the commercial than to the product

itself.
“It’s about basketball.” (Commercial for clothing)
“It’s about girls and shopping.” (Commercial for pizza)
“It’s for sports.” (Commercial for a beverage)
“I don’t know.” (Commercial for candy)

Boys have less tolerance when viewing commercials. 
"Fast forward through the commercials.”

“Can’t we just watch Nickelodeon?”

"You need to adjust the tracking, the quality’s bad.”

“How much longer do we have to sit here?”

“These commercials suck. I'm bored.”

“Can't we do this outside?”

"What's study hall mean?”

Girls seem to like girl commercials and respond to them very well. Girls pay more attention to the product then to what is going on in the commercial.

“Ahhhh, I love that product.”

"I have all of those."

“That's really cool.”

“That reminds me to ask my mom to get that for me.”

“Soooooo cute.”

Girls are less responsive toward boy commercials and neutral commercials. They tend to agree with boys when boys like something. However, it is important to realize that doesn't show that they would purchase a particular product because the boys liked it.

“It’s pretty cool.”

"I like the commercial."

“It’s cool, but I don’t want to buy it.”

\section{Commercials influence and motivate girls to crave more than boys.}

Girls watch commercials and immediately want the product or have a change in physical or emotional feelings.

“That makes me hungry!”

“That makes me thirsty."

“Can I have a drink?”

“Did you bring any of that for us?" 
“Ahhh, I want that.”

“That makes me think of bubble gum, now I want gum.”

Commercials do not influence boys as much. It was found that commercials make boys think of something completely different.

"I don’t want it.”

“I don’t like it.”

"It’s stupid.”

"I want to play football."

“I want to eat ice cream.”

"Why are you here?”

“Are you going to show this to your college friends?”

"Why are you taping us?”

\section{For the majority it was found that children don't pay much attention to} the gender of announcers or to background music.

When asked what the gender of the announcer was or how they liked the music

played in the background, some of the participants responses included:

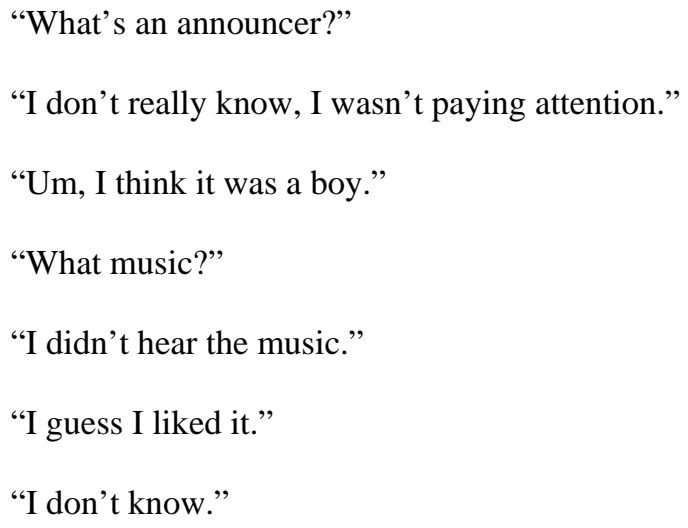




\section{Strengths and Limitations}

This field study, which was conducted in a naturalistic setting, was designed to investigate to which extent gender stereotypes in children's commercials affects consumer purchasing behavior. A full content analysis was conducted to seek gender stereotypes among children's commercials. Focus groups were conducted to seek out a correlation between stereotypes and purchasing behavior.

This two-pronged approach was based from the study conducted by Buijzen and Valkenburg, “The Impact of Television Advertising on Children’s Christmas Wishes.”93 They conducted a content analysis and a subsequent survey for their study, where in this research a content analysis and focus groups were conducted. This in certain ways is similar to agenda setting methodology. ${ }^{94}$ Traditionally, the theory of agenda setting assumes that public judgments of the importance of certain issues are a result of the prominence of those issues in the media. ${ }^{95}$ Agenda setting theory claims that the media determine what the audience thinks and talks about. ${ }^{96}$

The results of this research could be applied to the theory of agenda setting within the field of advertising. Television is a widely viewed medium by children. If children are exposed to the same commercials, they might put importance on the same issues. Commercials that are viewed repeatedly might not be telling children what to think, but what to think about which could have a direct effect on consumer purchasing behavior.

\footnotetext{
${ }^{93}$ Moniek Buijzen and Patti M. Valkenburg, "The Impact of Television Advertising on Children's Christmas Wishes,” Journal of Broadcasting \& Electronic Media 44, no. 3 (Summer 2000).

${ }^{94}$ Ibid., 463.

${ }^{95}$ Ibid.

${ }^{96}$ Ibid.
} 
There are some limitations that exist in the qualitative part of this study. First, it is important to note that qualitative research in the form of one-on-ones or focus groups have certain limitations. These studies are exploratory in nature and are generally used to get a range of responses, stimulate dialogue and generate ideas. Because of the limited number of participants, the discussion flow should not be considered conclusive or projectable to an entire population.

Another limitation has to do with the potential for participants to influence each other. Participants' responses may have been based around what the child before them had said. Here again, qualitative findings should not be projectable to an entire population.

The structure of the focus groups was another limitation in this study. Participants were taken from their ordinary after-school programs and put into a classroom with a video camera. Many of the participants were more concerned with being video taped and therefore many responses might not have been completely truthful. Even though most participants didn’t know each other and weren’t friends, responses could have also been manipulated by what was said by the older children.

\section{Conclusion}

This research was conducted to explore the benefits and deficits of pitching gender stereotypes to children and how the pitch, whether blatant or subtle, affected purchasing.

Gender stereotypes in children's television commercials have been widely studied for decades. This research intended to directly correlate gender stereotypes with differences in consumer purchasing behaviors. 
It was revealed that gender stereotypes in commercials influence boys differently than girls. Consistent findings and opinions that are interesting to consider include:

- There are many apparent and subtle gender stereotypes in children's television commercials, including the fact that there are more male characters that appear in neutral commercials and there are more male spokespeople in neutral commercials.

- Products advertised to girls are not meant to appeal to boys and boys want nothing to do with these products.

- Products advertised to boys are not meant to appeal to girls, however girls seem to like them anyway.

- Girls pay more attention to commercials and are manipulated more then boys, who would rather change the channel or engage in a different activity when commercials air.

- Consumer purchasing behaviors differ among boys and girls but that doesn't necessarily come from gender stereotypes in the commercials they view.

Although this research revealed that there are numerous gender stereotypes within commercials targeting children, the potential to directly correlate gender stereotypes with effects on consumer purchasing behaviors requires much more future research.

Future research would benefit this area of mass communication greatly. It would be necessary to analyze a larger sample of commercials and conduct more focus groups in different parts of the country. It would be beneficial to have participants view more commercials. It would also be beneficial to find out more about family life, 
demographics, television viewing habits and find out more in depth what the purchasing roles of the participants are. Ultimately, future research would benefit not only children, but the advertising world as well and how they implement strategies and tactics when selling to children. 


\section{Appendix A}

\section{Definition of Terms}

\section{Type of Advertisement}

PSA - Public service announcement

Testimonial - Any advertising message that consumers perceive as reflecting opinions, beliefs, or experiences of an individual, group, or institution. ${ }^{97}$

Generic - An advertisement that makes no effort at differentiation; claims could be made by any in the market. ${ }^{98}$

Unique Selling Proposition (USP) - An advertisement that uses a distinct differentiation that creates a meaningful consumer benefit. ${ }^{99}$

Brand Imaging - An advertisement that uses a claim of superiority or distinction based on extrinsic factors such as psychological differences in minds of consumers. $^{100}$

Positioning - Establishes a place in the consumer's mind relative to the competition. $^{101}$

\section{Role of Characters}

Action - The state of being very active.

Sedentary - Characterized by being inactive, i.e., standing or sitting.

\footnotetext{
${ }^{97}$ John Burnett and Sandra Moriarty, Introduction to Marketing Communications. Upper Saddle River, NJ: Prentice Hall. 1998. 209.

${ }^{98}$ Ibid., 289.

99 Ibid.

100 Ibid.

101 Ibid.
} 


\section{Behavior of Characters}

Anti-social - Associating in a non-normal or unfriendly way with others, i.e., fighting or yelling.

Social - Characterized by friendly relations or companionship. 


\section{Appendix B}

Overall Statistical Results for Seventy-Five Commercials Targeting

\section{Children}

TYPE OF ADVERTISMENT

\begin{tabular}{|c|c|c|c|c|}
\hline & & Frequency & Percent & $\begin{array}{c}\text { Valid } \\
\text { Percent }\end{array}$ \\
\hline Valid & USP & 32 & 42.7 & 42.7 \\
\hline & Positioning & 20 & 26.7 & 26.7 \\
\hline & $\begin{array}{c}\text { Brand } \\
\text { Image }\end{array}$ & 11 & 14.7 & 14.7 \\
\hline & Generic & 9 & 12.0 & 12.0 \\
\hline & PSA & 3 & 4.0 & 4.0 \\
\hline & Total & 75 & 100.0 & 100.0 \\
\hline
\end{tabular}

\section{PRODUCT}

\begin{tabular}{|c|c|c|c|c|}
\hline & & Frequency & Percent & $\begin{array}{c}\text { Valid } \\
\text { Percent }\end{array}$ \\
\hline Valid & Toys & 26 & 34.7 & 34.7 \\
\hline & Food & 20 & 26.7 & 26.7 \\
\hline & Entertainment & 12 & 16.0 & 16.0 \\
\hline & Accessories & 8 & 10.7 & 10.7 \\
\hline & Educational & 5 & 6.7 & 6.7 \\
\hline & Clothing & 3 & 4.0 & 4.0 \\
\hline & Other & 1 & 1.3 & 1.3 \\
\hline & Total & 75 & 100.0 & 100.0 \\
\hline
\end{tabular}

\section{NUMBER OF MALE CHARACTERS}

\begin{tabular}{|c|c|c|c|c|}
\hline & & Frequency & Percent & $\begin{array}{c}\text { Valid } \\
\text { Percent }\end{array}$ \\
\hline Valid & $0-2$ & 40 & 53.3 & 53.3 \\
\hline & $3-6$ & 24 & 32.0 & 32.0 \\
\hline & $7-10$ & 7 & 9.3 & 9.3 \\
\hline & 10 and up & 4 & 5.3 & 5.3 \\
\hline & Total & 75 & 100.0 & 100.0 \\
\hline
\end{tabular}


NUMBER OF FEMALE CHARACTERS

\begin{tabular}{|c|c|c|c|c|}
\hline & & Frequency & Percent & $\begin{array}{c}\text { Valid } \\
\text { Percent }\end{array}$ \\
\hline Valid & $0-2$ & 40 & 53.3 & 53.3 \\
\hline & $3-6$ & 24 & 32.0 & 32.0 \\
\hline & $7-10$ & 7 & 9.3 & 9.3 \\
\hline & 10 and up & 4 & 5.3 & 5.3 \\
\hline & Total & 75 & 100.0 & 100.0 \\
\hline
\end{tabular}

ROLE OF MALE CHARACTERS

\begin{tabular}{|c|c|c|c|c|}
\hline & & Frequency & Percent & $\begin{array}{c}\text { Valid } \\
\text { Percent }\end{array}$ \\
\hline Valid & Action & 45 & 60.0 & 60.0 \\
\hline & Sedentary & 17 & 22.7 & 22.7 \\
\hline & None & 13 & 17.3 & 17.3 \\
\hline & Total & 75 & 100.0 & 100.0 \\
\hline
\end{tabular}

\section{ROLE OF FEMALE CHARACTERS}

\begin{tabular}{|c|c|c|c|c|}
\hline & & Frequency & Percent & $\begin{array}{c}\text { Valid } \\
\text { Percent }\end{array}$ \\
\hline Valid & None & 31 & 41.3 & 41.3 \\
\hline & Sedentary & 30 & 40.0 & 40.0 \\
\hline & Action & 14 & 18.7 & 18.7 \\
\hline & Total & 75 & 100.0 & 100.0 \\
\hline
\end{tabular}

\section{SPEAKING PARTS FOR MALES}

\begin{tabular}{|c|c|c|c|c|}
\hline & & Frequency & Percent & $\begin{array}{c}\text { Valid } \\
\text { Percent }\end{array}$ \\
\hline Valid & $1-3$ & 46 & 61.3 & 61.3 \\
\hline & None & 24 & 32.0 & 32.0 \\
\hline & $4-6$ & 4 & 5.3 & 5.3 \\
\hline & 7 and up & 1 & 1.3 & 1.3 \\
\hline & Total & 75 & 100.0 & 100.0 \\
\hline
\end{tabular}


SPEAKING PARTS FOR FEMALES

\begin{tabular}{|c|c|c|c|c|}
\hline & & Frequency & Percent & $\begin{array}{c}\text { Valid } \\
\text { Percent }\end{array}$ \\
\hline Valid & None & 43 & 57.3 & 57.3 \\
\hline & $1-3$ & 31 & 41.3 & 41.3 \\
\hline & 7 and up & 1 & 1.3 & 1.3 \\
\hline & $4-6$ & 0 & 0.0 & 0.0 \\
\hline & Total & 75 & 100.0 & 100.0 \\
\hline
\end{tabular}

MALE BEHAVIOR

\begin{tabular}{|c|c|c|c|c|}
\hline & & Frequency & Percent & $\begin{array}{c}\text { Valid } \\
\text { Percent }\end{array}$ \\
\hline Valid & Social & 36 & 48.0 & 48.0 \\
\hline & Anti-social & 26 & 34.7 & 34.7 \\
\hline & None & 13 & 17.3 & 17.3 \\
\hline & Total & 75 & 100.0 & 100.0 \\
\hline
\end{tabular}

\section{FEMALE BEHAVIOR}

Characters - female behavior

\begin{tabular}{|c|c|c|c|c|}
\hline & & Frequency & Percent & $\begin{array}{c}\text { Valid } \\
\text { Percent }\end{array}$ \\
\hline Valid & Social & 42 & 56.0 & 56.0 \\
\hline & None & 32 & 42.7 & 42.7 \\
\hline & Anti-social & 1 & 1.3 & 1.3 \\
\hline & Total & 75 & 100.0 & 100.0 \\
\hline
\end{tabular}


ANNOUNCERS

\begin{tabular}{|c|c|c|c|c|}
\hline & & Frequency & Percent & $\begin{array}{c}\text { Valid } \\
\text { Percent }\end{array}$ \\
\hline \multirow[t]{5}{*}{ Valid } & \begin{tabular}{|c|} 
Male \\
announcer \\
not shown \\
\end{tabular} & 54 & 72.0 & 72.0 \\
\hline & \begin{tabular}{|c|} 
Female \\
announcer \\
not shown
\end{tabular} & 17 & 22.7 & 22.7 \\
\hline & \begin{tabular}{|c|} 
Female \\
announcer \\
shown
\end{tabular} & 3 & 4.0 & 4.0 \\
\hline & \begin{tabular}{|c|} 
Male \\
announcer \\
not shown
\end{tabular} & 1 & 1.3 & 1.3 \\
\hline & Total & 75 & 100.0 & 100. \\
\hline
\end{tabular}

\section{SETTING - WHERE IT TOOK PLACE}

\begin{tabular}{|c|c|c|c|c|}
\hline & & Frequency & Percent & $\begin{array}{c}\text { Valid } \\
\text { Percent }\end{array}$ \\
\hline Valid & Indoors & 38 & 50.7 & 50.7 \\
\hline & Both & 22 & 29.3 & 29.3 \\
\hline & Outdoors & 13 & 17.3 & 17.3 \\
\hline & Other & 2 & 2.7 & 2.7 \\
\hline & Total & 75 & 100.0 & 100.0 \\
\hline
\end{tabular}

\section{SETTING - TYPE}

\begin{tabular}{|c|c|c|c|c|}
\hline & & Frequency & Percent & $\begin{array}{c}\text { Valid } \\
\text { Percent }\end{array}$ \\
\hline Valid & Realistic & 42 & 56.0 & 56.0 \\
\hline & Combination & 19 & 25.3 & 25.3 \\
\hline & Cartoon & 11 & 14.7 & 14.7 \\
\hline & Claymation & 3 & 4.0 & 4.0 \\
\hline & Total & 75 & 100.0 & 100.0 \\
\hline
\end{tabular}




\section{SITUATION TYPE}

Situation Type

\begin{tabular}{|c|c|c|c|c|}
\hline & & Frequency & Percent & $\begin{array}{c}\text { Valid } \\
\text { Percent }\end{array}$ \\
\hline Valid & Playtime & 19 & 25.3 & 25.3 \\
\hline & Fashion/Trends & 15 & 20.0 & 20.0 \\
\hline & Action/Adventure & 14 & 18.7 & 18.7 \\
\hline & Other & 11 & 14.7 & 14.7 \\
\hline & Fantasy & 9 & 12.0 & 12.0 \\
\hline & Real Life & 7 & 9.3 & 9.3 \\
\hline & Total & 75 & 100.0 & 100.0 \\
\hline
\end{tabular}

\section{MUSIC}

Music
\begin{tabular}{|c|c|c|c|c|}
\hline & & Frequency & Percent & $\begin{array}{c}\text { Valid } \\
\text { Percent }\end{array}$ \\
\hline Valid & $\begin{array}{c}\text { Fast } \\
\text { Paced }\end{array}$ & 27 & 36.0 & 36.0 \\
\hline & Hip Hop & 21 & 28.0 & 28.0 \\
\hline & None & 11 & 14.7 & 14.7 \\
\hline & $\begin{array}{c}\text { Slow } \\
\text { Paced }\end{array}$ & 6 & 8.0 & 8.0 \\
\hline & Other & 4 & 5.3 & 5.3 \\
\hline & action & 2 & 2.7 & 2.7 \\
\hline & Romantic & 2 & 2.7 & 2.7 \\
\hline & Rap & 2 & 2.7 & 2.7 \\
\hline & Total & 75 & 100.0 & 100.0 \\
\hline
\end{tabular}




\section{Bibliography}

Bauer, Raymond A. and Stephen A. Greyser. Advertising in America: The Consumer View. Boston: Division of Research, Harvard Business School, 1968.

Britt, Steuart Henderson. Psychological Experiments in Consumer Behavior. New York: John Wiley \& Sons, Inc., 1970.

Buijzen, Moniek, and Patti M. Valkenburg. “The Impact on Television Advertising on Children's Christmas Wishes.” Journal of Broadcasting \& Electronic Media 44, no.3 (Summer 2000), 456-471.

Burnett, John, and Sandra Moriarty. Introduction to Marketing Communications. Upper Saddle River, NJ: Prentice Hall, 1998.

Chandler, Daniel, and Merris Griffiths. "Gender-Differentiated Production Features in Toy Commercials.” Journal of Broadcasting \& Electronic Media 44, no. 3 (Summer 2000), 503-521.

Children Now. "New Studies on Media, Girls, and Gender Roles: Media Reinforces Some Gender Stereotypes, Breaks Others,” for immediate release. April 30, 1997.

Center for Media Education. “Children \& Television: Frequently Asked Questions.” Available from www.cme.org/children/kids_tv/c_and_t.html; Internet. March 3, 2003.

Committee on Consumer Policy. Advertising Directed at Children. France: OECD, 1982.

Cook, Daniel Thomas. “The Other 'Child Study': Figuring Children as Consumers in Market Research, 1910s-1990s.” Sociological Quarterly 41, no.3 (Summer 2000), 487-508.

Dumont, Pascaline. “Temptation-free Television for Children?” UNESCO Courier 54, no. 9 (Sept. 2001), 44-48.

Federal Trade Commission. "Children as Consumers of Entertainment Media: Media Usage, Marketing Behavior and Influences, and Rating Effects.” Congressional Information Service, Policy Papers, (Sept. 1, 2000).

Goulart, Ron. The Assault on Childhood. Los Angeles: Sherbourne Press, Inc., 1969.

Geis, Michael L. The Language of Television Advertising. New York: Academic Press, 1982. 
Heintz-Knowles, Katherine and Meredith Li-Vollmer. "Boys to Men, Entertainment Media: Messages About Masculinity.” Report from Children \& the Media $\backslash$ Program at Children Now. September 1999.

Kolbe, Richard H. and Darrell Meuhling. “Gender Roles \& Children’s Television Advertising.” Journal of Current Issues and Research in Advertising 17, no. 1

Lawler, Edmund O. "Marketing to Kids, Tweens and Teens.” Advertising Age. February 17, 2003.

MediaFamily.org. “The Teaching Power of Television Advertising,” Newsletter.

Moschis, George P. Consumer Socialization: A Life-Cycle Perspective. Massachusetts: Lexington Books, 1987.

O’Barr, William M. “Interview with Paul Kurnit.” Advertising \& Society Review E, no. 1534-7311, 1-57.

Pecora, Norma Odom. The Business of Children's Entertainment. New York: Guilford Press, 1998.

Qayumi, Shahnaz. "Piaget and His Role in Problem Based Learning." Journal of Investigative Surgery 14 (2001), 63-65.

Rossiter, John R. and Thomas S. Robertson. “Children’s Television Viewing: An Examination of Parent-Child Consensus.” Sociometry 38, no. 3 (Sept. 1975), 308-326.

Sheehan, Daniel. “A Primer on Multiple Intelligence.” NEA Today 15, no. 17 (March 1997), 17.

Signorelli, Nancy. “A Content Analysis: Reflections of Girls in the Media.” Kaiser Family Foundation. April, 1997.

Sutherland, Max and Alice K. Sylvester. Advertising and the Mind of the Consumer: What works, what doesn't and why. Australia: Griffen Press, 2000.

Van Manen, Teun G., Pier J.M. Prins and Paul M.G. Emmelkamp. “Assessing Social Cognitive Skills in Aggressive Children from Development Prospective: The Social Cognitive Skills Test.” Clinical Psychology and Psychotherapy 8 (2001), 341-351.

Wartella, Ellen and Katharine Eliza Heintz. “Television and Beyond.” Communication Research 17, no. 1 (Feb. 1990), 45-65. 
Weiland, Stephen. "Erik Erikson: Ages, Stages, and Stories.” Generations 17, no. 2, 1723.

Welch, Renate L., Althea Huston-Stein, John C. Wright and Robert Plehal. "Subtle SexRole Cues in Children's Commercials.” Journal of Communication 29, no. 3 (Summer 1979). 202-209

Winick, Charles, Lorne G. Williamson, Stuart F. Chuzmir, and Mariann Pezzella Winick, eds. Children's Television Commercials: A Content Analysis. New York: Praeger Publishers, 1973. 